\title{
Editorial
}

\section{The Apple Ruling or the Destruction of the Ring to Bind Them All}

Fiscal aid represents perhaps the intellectually most challenging aspect which the application of the Treaty's rules on this pillar of EU competition law has to offer. And it is always the criterion of material selectivity which lies in the epicentre of the analysis. The latter criterion I have once compared to a jellyfish, meaning that in the very moment you have reached a level of sufficient confidence to finally grasp it, it slips out of your hands again.

It has now been the European Commission that had to experience this jellyfish nature. Since old and new Competition Commissioner Margrethe Vestager has taken office in 2014, one could at times not avoid getting the impression that EU State aid control covers little more than scrutinising so-called 'Tax Rulings'. In those cases national tax offices assure multinational companies to tax them in a specific way, more precisely to have their taxable income calculated in a specific manner agreed on between the administration and the company ex ante. In the Apple Ireland case the Commission found in late August 2016 that two such rulings of the Irish tax office dating back to 1991 and 2007 had reduced the tax base of the US tech giant in a way running counter to the prohibition to grant illegal State aid (see Commission Decision of 30 August 2016, Case SA.38373). This in turn led the Commission to ask Apple to reimburse some $€_{13}$ billion to the Irish treasury. The Apple case strongly reminds of the most powerful in the set of rings that J.R.R. Tolkien's world-famous novel centres on, a ring he describes as follows: 'One ring to rule them all, one ring to find them, one ring to bring them all and in the darkness bind them!'.

In Professor Tolkien's story the destruction of the mightiest of all rings could however only happen in the place where it had been created, meaning that the one who aimed to destroy it was compelled to succeed throwing it into the fires of Mount Doom in the land of Mordor, where Lord Sauron had once forged it. The destruction of the mightiest of all rings that the Brussels-based Competition Commissioner had forged, respectively had ordered her services to forge, has recently been achieved in the chambers of the EU General Court on 15 July 2020. In a ruling, which received widespread attention far beyond the small community of State aid wizards, the Court found that the general approach to scrutinise tax rulings on the basis of EU State aid rules could not be challenged as such. This means the Commission did not act 'ultra vires' when applying the prohibition as laid down in Article 107 (1) TFEU to such rulings. And despite rejecting the Commission's premiss that the so-called 'arm's length'-principle, which it had employed to look into whether a company had enjoyed an economic advantage, flowed directly from Article 107 (1) TFEU, it still approved of the application of this principle to the extent that it formed part of the respective national tax laws.

But this is where the sun stopped shining on the Commission's decision. Thereafter the sky started to darken and lightning, thunder, and hail set in. As to the Commission's primary line of reasoning, ie that the revenues of two Irish Apple subsidiaries had been wrongly calculated because the IP licences the latter used should have been attributed to them, the Court concluded that the Commission had misinterpreted the pertinent Irish tax laws and - most specifically so - had not succeeded in showing that those licences had been under the control of said 
subsidiaries. As to the Commission's subsidiary line of reasoning it held that despite the fact that the method forming the basis of the contested tax rulings revealed a series of methodological mistakes, these mistakes did not suffice to show the presence of an aid. Consequently, the Court rejected the assumption that the turnovers resulting from the exploitation of these licences would have had to be included in the company's taxable base. And, finally, the alternative line of reasoning likewise failed because, in the Court's view, the sole fact that the tax rulings had been adopted in a discretionary manner was not enough to show a violation of the rules on State aid. Moreover, it would have been required for the Commission to prove a causal link between said discretion and the presence of an economic benefit.

Given the fact that all these criticisms voiced by the Court rely on facts rather than on law, the task of finding grounds to appeal this ruling seems a rather demanding one. Maybe, before adopting the verdict against Apple, Competition Commissioner Vestager should therefore have followed the advice rendered by famous Bavarian comedian Karl Valentin. He had put it like this in my own unofficial translation of one of his legendary proverbs into the English language:

'Liking it I could well have wanted, but being allowed to I didn't dare to'.

Andreas Bartosch*

* Dr Andreas Bartosch, Bartosch EU Law, Brussels. For correspondence: <Andreas.Bartosch@eurojura.be>. 